\title{
The Role of Family Social Support on Learning Motivation: A Study on High School Students
}

\author{
Frency Manasye Pieters ${ }^{1 *}$ Agustina Agustina ${ }^{1}$ \\ ${ }^{1}$ Psychology Undergraduate Program, Universitas Tarumanagara, West Jakarta, Indonesia \\ *Corresponding author. Email: agustina@fpsi.untar.ac.id
}

\begin{abstract}
With the increasing number of deaths and cases of corona virus, the government came up with several policies, including large-scale social restrictions (PSBB). These restrictions include restrictions in schools. Learning methods that used to be face-to-face became online learning. Motivation to learn is a process of activity that gives energy, and directs one's behavior to achieve one's goals. The purpose of this study is to determine the effect of family social support on high school student learning motivation during online learning. This research uses quantitative research methods. The data used in this study were collected from 103 respondents with the criteria such as between the age of 15-19 years old and are currently undergoing online learning. The study participants were selected by purposive sampling. The data were processed using linear regression. Based on the results of the regression test between family social support and learning motivation, the value of sig 0.040 $(<0.05)$ and $t-2.077$ is obtained, therefore, there is a significant negative effect between family social support on learning motivation of high school students.
\end{abstract}

\section{Keywords: Learning motivation, high school students, family social support, online learning}

\section{INTRODUCTION}

At the end of 2019, Indonesia received the news about the spread of the Corona virus in Wuhan, China which caused the Covid-19 disease [1]. Data on the WHO website, on March 2, 2020, 6 cases were found who were exposed to the Corona virus in Indonesia, then the first death case on March 12, 2020 [1]. The increasing number of deaths and cases exposed to the Corona virus around the world is considered a pandemic. Efforts made by the government to deal with the pandemic include the implementation of PSBB (Large-Scale Social Restrictions). The purpose of the PSBB is to prevent the spread of the COVID-19 virus. Restrictions on activities include the dismissal of schools and workplaces, religious restrictions and on other activities in public places. [2].

Online learning has become a solution to continue learning from home, eliminating the need to meet face-to-face. Every change that occurs have a positive or negative impact. The positive impact is that online learning allows students to have a more flexible study time so that they can study anytime and anywhere, and learning resources apart from books can be found on the internet. With online learning, there were several obstacles that were found, both for teachers and students. Data limit can be a problem for students who experience financial constraints. Although closing schools can save lives, it also poses challenges for children who come from low-income families. For them, it is difficult to access long distance learning [3]. This condition causes student learning motivation to decrease and even affects student learning outcomes [4].
Motivation is a process that energizes, directs, and sustains behavior [5]. Furthermore, Santrock [5] stated that there are two factors that influence student learning motivation, namely intrinsic motivation and extrinsic motivation. Extrinsic motivation is a motivation originating from outside oneselves such as reward or punishment, while intrinsic motivation is motivation from oneself. According to Wlodkowski and Jaynes [6], there are various factors that influence the level of motivation to learn, one of which is social support from the surrounding environment, especially from the family. Research conducted by Cirik [7] shows that social support from family influences students' learning motivation.

According to Sancahya and Susilawati [8], family social support includes physical and psychological comfort, attention, appreciation, and other forms of assistance that an individual receives from his/her father, mother, or siblings. The family environment is the main pillar that shapes children to be independent, the greatest support in the home environment comes from parents where children can develop their abilities, learn to take initiatives, make decisions about what they want to do and learn to be responsible for all their actions [9]. When learning online, parents also act as guides and motivators for children at home. According to an interview by Radar Sumbawa [10], there are several obstacles, including parents having to spend time to help with homework and guide children during online learning, and inability to operate online learning applications.

During this pandemic, Zain [11] said that teenagers are prone to BLAST (Bored, Lonely, Angry, and Tired) 
because they often use smartphones. Zain [11] also mentions in his writing that high school is a wonderful time to enjoy friendship at school, however, pandemic forced them to stay at home and learn from home with their family. This is why they need support from families in order to continue to grow according to their psychosocial stages, even at home. The role of parents is to remind their children to do assignments, and parents should not hesitate to convey constraints to the teacher [12] In addition, some students filled out a short survey by the authors where they claimed that they needed support such as having a quiet home atmosphere when learning online takes place, needing attention, having their effort appreciated and not only the result.

Online learning is learning that utilizes internet network, with accessibility, connectivity, flexibility, and the ability to generate various types of learning interactions. [19] Online learning media can be conducted through Whatsapp group, zoom, google meets, and google classroom [20].

Previous research conducted by Prasetyo and Rahmahsari [6] shows that there is a significant relationship between family social support and student motivation to learn. Student motivation to learn can be built by the family. Strong social support is accepted, especially in. The contribution given by family social support in this study is quite large on student learning motivation. According to study conducted by Cahyani, Listiana, and Larasati there is significantly decreased learning motivation in online learning when pandemic situation [18].

With the pandemic in mind, and based on previous research, the authors are interested in finding out more about the role of family social support on learning motivation in high school students.

\subsection{Paper Structure}

Systematically, this study was written into five chapters. The first part contains a description of the discussion on the background of the problem, problem formulation, research objectives, previous research and systematics of writing. The second part contains a description of the theory which forms the basis of the theory in this study and the framework. Meanwhile, the theory used was the theory of family social support theory, the theory of learning motivation. The third section contains a part of the research methodology which contains criteria and descriptions of participants, types of research, research settings and tools, research measurement tools, research preparation, and implementation, as well as data processing and analysis techniques. The fourth section contains a discussion of the results of the main data analysis and additional data. The fifth part is the closing which contains conclusions.

\section{BACKGROUND}

\subsection{Social Support Family}

The operational definition of family social support according to Sancahya and Susilawati [8] is physical and psychological comfort, attention, appreciation, and other forms of assistance that an individual receives from the individual's father, mother, or sibling. There are 4 forms of family social support according to House [13] namely: a) Emotional support which includes expressions of empathy, sympathy, willing to hear complaints, even willing to help solve the problems they face; b) Appraisal support is a form of appreciation given to another party based on the actual condition of the sufferer. Based on the social family, what is given is a positive assessment. c) Instrumental support includes direct assistance, such as when someone lends money to someone or helps with a favor at a time of stress; d) Information support, which can be provided through the provision of advice, hints, suggestions or feedback.

\subsection{Learning Motivation}

According to Schunk, et al [14], the term motivation comes from the Latin verb movere which means 'to move'. Motivation is the process of energizing, directing, and supporting behavior [5]. Motivation is a conscious effort to move, direct, and maintain one's behavior in order to be motivated to do something so as to achieve goals [15]. Maslow in 1970 [16] argued that motivation is complex, therefore, a person's behavior originates from a separate motive. Furthermore, there is a possibility that the motivation for a behavior is not realized or not known by the person. According to Worell and Stiwell [17] there are 3 positive aspects of student learning motivation such as: a) Showing interest, attention, and participation in learning; b) Working hard and allocating time to tasks; c) Keep working until the task is completed.

Motivation is divided into two types, namely intrinsic and extrinsic motivation. According to Santrock [5] extrinsic motivation is motivation that is usually influenced by factors outside oneself. A person is extrinsically motivated to perform a task because they believe that participation will produce the desired outcome such as reward, teacher praise, or punishment avoidance [14]. Meanwhile, intrinsic motivation is motivation to do something for oneself [5], for example, someone studies hard in order to enter the college one dreams of.

\subsection{High School Student}

High school students, according to Santrock are individuals who enter adolescence, where there are myriad of problems due to experiencing new changes [18]. Santrock [5] stated that adolescence starts from the age range of 10 to 21 years. Meanwhile, according to the psychosocial stage according to Erikson, adolescents are in the 5th stage, where there is identity versus identity confusion in the age range of 10-20 years [5]. In the identity versus identity confusion psychosocial stage, adolescents seek to find out who they are, their goals in life, and if they are not allowed to explore different roles, then in the future they will remain confused about their identity [5].

Compared with children, adolescents have an increased capacity to monitor and manage cognitive resources 
effectively to meet the demands of learning tasks [5]. According to Santrock [9] adolescence is a transitional developmental period between childhood and adulthood which includes biological, cognitive, and social emotional changes. According to Reyna and Zayas, adolescence is a time of decision making, such as which friends to choose, which people to date, whether to have sex, whether to seek immediate gratification or delay gratification in exchange for positive results, whether to go to college, and so on [5]. High school students are included in the late adolescence phase, because high school students are in the age range of 16-18 years.

\section{METHODS}

\subsection{Participants and Procedure}

The subject criteria in this study are high school students, aged around 15-19 years, who were undergoing online learning, either male or female. They must also be willing to be a research participant by filling out the informed consent contained in the google form. The sampling technique used was purposive sampling, because when a person meets the criteria, they can become a participant in this study. The study involved 103 high school students in Indonesia consisting of $68(66 \%)$ female participants and 35 $(34 \%)$ male participants.

This is a quantitative, non-experimental study. Quantitative research is the activity of processing, collecting, analyzing, and presenting data based on the number that is conducted objectively to solve a problem or test a hypothesis to develop general principles [21]. The questionnaire in the study was distributed using Google Form. After that, Statistical Product and Service Solution (SPSS) version 23.0 was used to process data.

\subsection{Research Instruments}

The learning motivation scale compiled by Farid is based on the aspects of learning motivation proposed by Worell and Stilwell [22]. The type of scale used is a Likert scale with four answer choices, which are Strongly Agree (SS), Agree (S), Disagree (ST), Strongly Disagree (STS). The learning motivation scale consists of 40 statement items with 20 negative items and 20 positive items. This scale consists of several dimensions, including: (a) being diligent in dealing with the task consists of 8 statement items with 4 positive items and 4 negative items; (b) resilience in responding to difficulties, which has 8 items consisting of 4 positive points and 4 items; (c) showing interest in various problems, which has 8 statements consisting of 4 positive and 4 negative items; (d) preferring to work independently, which has 8 statement items consisting of 4 negative points and 4 positive points; (e) difficulty in letting go of your beliefs (Having positive expectations), which has 8 statements consisting of 4 positive items and 4 negative items.
The family social support scale was compiled by Rayyan [23], based on indicators by House, et al. (1994) which consists of the aspects of emotional support, appreciation, information and instrumental. The type of scale used is a Likert scale with four answer choices, namely Strongly Agree (SS), Agree (S), Disagree (ST), Strongly Disagree (STS). The family social support scale consists of 35 statement items consisting of 17 positive items and 18 negative items. This family social support scale consists of 4 dimensions, namely: (a) Emotional Support, with 8 statement items consisting of 4 positive items and 4 negative items; (b) Award Support, with 10 statement items consisting of 4 positive points and 6 negative points; (c) Instrumental Support, with 8 statement items consisting of 4 positive points and 4 negative points; (d) Informative Support, with 9 statement items consisting of 5 positive points and 4 negative points.

\section{FINDINGS AND DISCUSSIONS}

This section will explain and answer the main questions of this research regarding whether or not family social support has an influence on high school student learning motivation during online learning. The researcher conducted normality test, followed by linear regression method. The data processing used in this study was assisted by the SPSS program version 23.0.

Normality test was conducted to prove whether the residual value is normally distributed or not. The normality test used in this study is the Kolmogorov Smirnov test, which showed that the family social support and learning motivation of high school students in online learning is normally distributed. Distribution is said to be normal if the distribution value, namely the $\mathrm{p}$-value, is greater than 0.05 $(\mathrm{p}>0.05)$.

Table 1 Kolmogorov-Smirnov normality test

\begin{tabular}{ccc}
\hline Variable & $\begin{array}{c}\text { Kolmogorov } \\
\text { Smirnov } \boldsymbol{Z}\end{array}$ & $\mathbf{p}$ \\
\hline & & \\
Family Social Support & .063 & .200 \\
Learning Motivation & .082 & .081 \\
\hline
\end{tabular}

The result of the linear regression test between family social support on the learning motivation of high school students found $\beta=-156 p=0.040$, so that it can be interpreted that the value is found to be significant. The linear regression equation between family social support on high school student learning motivation is $\mathrm{Y}=3.217-0.156 \mathrm{x}$. The result is $t=-2.077$ and $p=0.040(<0.05)$. Based on the results obtained, it can be concluded that family social support has a significant negative effect on student learning motivation. The results of the regression test for family social support on learning motivation can be seen in Table 2. 
Table 2 Linear regression test between family social support on high school student learning motivation Coefficients $^{\mathrm{a}}$

\begin{tabular}{|c|c|c|c|c|c|c|c|c|}
\hline \multirow{2}{*}{\multicolumn{2}{|c|}{ Model }} & \multicolumn{2}{|c|}{$\begin{array}{l}\text { Unstandardized } \\
\text { Coefficients }\end{array}$} & \multirow{2}{*}{$\begin{array}{c}\text { Standardized } \\
\text { Coefficients } \\
\text { Beta } \\
\end{array}$} & \multirow[b]{2}{*}{$\mathrm{t}$} & \multirow[b]{2}{*}{ Sig. } & \multicolumn{2}{|c|}{$\begin{array}{l}\text { Collinearity } \\
\text { Statistics }\end{array}$} \\
\hline & & B & Std. Error & & & & Tolerance & VIF \\
\hline \multirow[t]{2}{*}{1} & (Constant) & 3.217 & .146 & & 22.042 & .000 & & \\
\hline & DSK & -.156 & .075 & -.202 & -2.077 & .040 & 1.000 & 1.000 \\
\hline
\end{tabular}

a. Dependent Variable: motivation

The descriptive statistical test of the family social support variable found an empirical mean smaller than the hypothetical mean $(1.8294<2.50)$. Then, the descriptive statistical test of the learning motivation variable obtained an empiric mean greater than the hypothetical mean $(2.8723$ > 2.50). With significant negative result, it can be said that because the subjects already show high internal motivation, the external motivation obtained from other people, especially in this case the parents, becomes less influential. In addition, the questionnaire in this study leans more towards internal motivation. It can be illustrated through this research that during online learning, high school students still possess high learning motivation. In line with a research by Willyana [24], it is stated that if family support is considered high, it cannot be ascertained that learning motivation in students is also high because family support does not fully affect student learning motivation. There are other factors that can affect student learning motivation. It is also in line with an interview with the parents of students in the article Ayo Bandung [25] which claimed that parents should not meddle too much, but to serve as facilitators, because children can complete their own tasks. This is in accordance with the development of adolescents that adolescents have an increased capacity to monitor and manage cognitive resources effectively to meet the demands of learning tasks [5]. The article also explains that in fact, not all parents are able to support their children when studying online, apart from the lack of insight and lack of knowledge, but also financial issues and reduced income in these circumstances. Therefore, when linked to the results of this study, because children already possess independence and high learning motivation or high intrinsic motivation, family social support seems less influential.

In additional data, the researcher wanted to see the relationship between dimensions of the two variables, namely family social support and learning motivation. It was found that emotional support, informational support, reward support and instrument support have a relationship to the dimensions of interest in various problems and prefer to work independently. Based on research by Farid, there are indicators in each dimension. The dimension of interest in various kinds of problems has indicators that see each problem can be solved and a desire to correct past failures. The dimension of preferring to work independently has indicators, namely having a positive view of their abilities and the existence of responsibility for the assigned task. [26]. In line with research by Sinaga [27], which is one that affects learning independence, namely the source of the family environment so that students can be responsible for the assignment given. With emotional support, informational, appreciation, and instruments to students, a student will see that every problem can be solved independently both in academic and non-academic [27]. As for the dimensions of resilience in responding to difficulties, being diligent in facing tasks, not being easy in letting go of things that are believed (expectations, curiosity in acquiring knowledge) are dimensions that arise from oneself so that they are less connected with others.

\section{CONCLUSIONS}

The purpose of this study is to determine the effect of family social support on learning motivation of high school students undergoing online learning. Based on the data analysis, it is found that family social support has a significant negative effect on the motivation of high school students undergoing online learning. Even though family social support is low, the motivation to learn in online learning is still high. Suggestion for parents is to keep paying attention and supporting their children's positive activities. Although family social support is less influential towards learning motivation, children still need parental figures in their development.

Researchers are aware that there are still many limitations in this study. First, due to the Covid-19 pandemic, the researchers cannot visit schools to distribute questionnaires and cannot supervise the questionnaire filling process directly. Second, because it took approximately a week to distribute the questionnaires, the number of participants was limited. Third, there are more items in the questionnaire which measures intrinsic motivational.

\section{ACKNOWLEDGMENT}

Researchers would like to thank all who contributed to this research, especially the university who has guided the researchers and to every participant who has been willing to fill out the questionnaire. 


\section{REFERENCES}

[1] World Health Organization, WHO coronavirus disease (COVID-19) dashboard. WHO https://covid19 .who.int/table (October 10, 2020).

[2] D. N. Sari, Efek samping dari psbb terhadap masyarakat. Suara.com. https://www.suara.com/ yoursay/2020/04/16/171009/efek-samping-psbbterhadap-masyarakat?page=all (April 16, 2020).

[3] Arnolduswea, Pandemi dan keberlanjutan pendidikan kita. AWStore. https://arnolduswea.com/ gagasan/pandemi-dan-tantangan-persoalanpendidikan-kita/ (August 9, 2020)

[4] N. Ainun. Motivasi belajar siswa dalam pembelajaran selama pandemi covid-19. Kompasiana, https://www.kompasiana.com/nurainun1970/5f338d87 097f36620e4e0d03/motivasi-belajar-siswa-dalampembelajaran-selama-pandemi-covid-19?page $=$ all (Augustus 12, 2020).

[5] J. W. Santrock, Educational Psychology, McGrawHill Education, 2017.

[6] K. B. Prasetyo, D. Rahmasari, Hubungan antara dukungan social keluarga dengan motivasi belajar pada siswa. Jurnal Penelitian Psikologi. 7(1) (2016) 1-9. http://jurnalfpk.uinsby.ac.id/index.php/JPP/article/view 192

[7] I. Cirik, Relationships between social support, motivation, and science achievement: structural equation modeling. Antropologist. 20(1,2) (2015) http://krepublishers.com/02-Journals/T-Anth/Anth-200-000-15-Web/Anth-20-1-000-15-Abst-PDF/T-ANTH -20-1,2-232-15-1438-Crk-I/T-ANTH-20-1,2-232-151438-Crk-I-Tx\%5B26\%5D.pdf

[8] A. A. G. A. Sancahya, L. K. P. A. Susilawati, Hubungan antara dukungan social keluarga dengan self esteem pada remaja akhir di kota Denpasar. Jurnal Psikologi Udayana. 1(3) (2014) 52-52. https:// simdos.unud.ac.id/uploads/file_penelitian_1_dir/8a5ec fb $2 \mathrm{a} 49 \mathrm{~d} 3 \mathrm{c} 42 \mathrm{c} 5 \mathrm{f} 25453 \mathrm{bdad} 755 \mathrm{c}$.pdf

[9] J. W. Santrock, Adolescence: Perkembangan Remaja. (edisi keenam). Penerjemah: Shinto B. Adelar \& Sherly Saragih. Erlangga, 2003.

[10] Redaksi, Peran tekhnologi, guru, dan orang tua dalam pembelajaran daring di masa pandemi. Radar Sumbawa, https://radarsumbawa.id/2020/10/27/perantekhnologi-guru-dan-orang-tua-dalam-pembelajarandaring-di-masa-pandemi (October 27, 2020).
[11] N. A. Zain, Peran guru dan orang tua dalam perkembangan remaja selama pandemi. Inisiator, https://inisiator.com/peran-guru-dan-orang-tua-dalamperkembangan-remaja-selama-pandemi/ (Mei 22, 2020).

[12] Santuso. Dampak pembelajaran jarak jauh bagi siswa, butuh peran orang tua untuk mengatasinya. Kompasiana.https://www.kompasiana.com/sts_santuso /5f69df58097f36456875e4b2/dampak-pembelajaranjarak-jauh-bagi-siswa-butuh-peran-orang-tua-untukmengatasinya?page=all $($ September 22, 2020)

[13] Harnilawati, Konsep dan proses keperawatan keluarga, Pustaka As Salam, 2013.

[14] D. H. Schunk, J. Meerce, P. R. Pintrich, Motivation in education theory, research, and applications. Pearson, 2014.

[15] G. Hamdu, L. Agustina, Pengaruh motivasi belajar siswa terhadap prestasi belajar ipa di sekolah dasar. Portal Jurnal Universitas Pendidikan Indonesia. 12(1) (2011).

[16] J. Feist, \& G. J. Feist, Theories of Personality, $9^{\text {th }}$ Edition. McGraw-Hill Education, 2017.

[17] Nursalam., F. Effendi, Pendidikan Dalam Keperawatan. Salemba Medika, 2008.

[18] A. Cahyani, I. D. Listiana, S. P. D. Larasati, Motivasi belajar siswa SMA pada pembelajaran daring di masa pandemic covid-19, Jurnal Pendidikan Islam. 3(1), 2020, pp. 123-140. DOI: https://doi.org/10. 37542/iq.v3i01.57

[19] M. Yuliani, J. Simamarta, S. S. Susanti, E. Sudra, R.I. Mahawati, H. Dwiyanto, Pembelajaran daring untuk pendidikan: Teori dan penerapan. Yayasan Kita Menulis, 2020.

[20] S. Ramdhani. Media komunikasi dalam pembelajaran daring selama masa pandemi. Kompasiana. https://www.kompasiana.com/ sitiramadhani/5f36c1f1097f360e897d3922/mediakomunikasi-dalam-pembelajaran-daring-selama-masapandemi-covid-19 (Agustus 15, 2020).

[21] N. Dulu, (2019) Metedologi Penelitian Kuantitatif: Beberapa Konsep Dasar untuk Penlulisan Skripsi \& Analisis Data dengan SPSS. Deepublish

[22] M. Farid, (2017) Hubungan Persepsi terhadap Iklim Kelas dengan Motivasi Belajar Siswa Kelas 10 SMA Negeri 10 Medan. Skripsi. Fakultas Psikologi Universitas Medan Area. 
[23] R. A. Linasta, (2017). Hubungan Dukungan Sosial Orangtua terhadap Motivasi Belajar Siswa. Skripsi. Fakultas Psikologi Universitas Muhammadiyah Malang.

[24] M. A. D. Willyana, (2015). Hubungan Antara Dukungan Keluarga dengan Motivasi Belajar pada Siswa SMA. Skripsi. Universitas Muhammadiyah Surakarta.

[25] M. N. Hafizh, Sistem belajar daring, tak semua orang tua mampu 'dukung' anak. Ayobandung.com https://ayobandung.com/read/2020/07/14/106421/siste $\mathrm{m}$-belajar-daring-tak-semua-orang-tua-mampudukung-anak (July 14, 2020).

[26] Farid, M. (2017). Hubungan Persepsi terhadap Iklim Kelas dengan Motivasi Belajar Siswa Kelas X SMA Negeri 10 Medan. Skripsi. Fakultas Psikologi Universitas Medan.

[27] J. D. Sinaga. Tingkat dukungan orang tua terhadap belajar siswa, Indonesian Journal of Education Counseling, 2(1), 2018, pp 43-54. DOI: 10.30653/ 001.201821 .19 